\title{
THE PROBLEMS OF ROBOTISATION OF LEGAL PROFESSION
}

\author{
Albina Sh. Khabibullina ${ }^{1}$ \\ Stella B. Seleckaya ${ }^{2}$ \\ Aleksandr N. Shpagonov ${ }^{3}$
}

Abstract: This paper is devoted to the analysis of the legal activity digitalization problems. In the course of the study of the stated problems, the authors come to the conclusion that today the thesis about the complete replacement of lawyers by robots and the disappearance of the legal profession is unreasonable and premature.According to the authors of the paper, it is impossible to completely trust artificial intelligence to solve legal issues. Currently, a robot can replace a lawyer only in execution of programmable routine tasks, such as drawing up a simple template contracts, claims, search for court practice materials, analytical information, transfer documents to the court, etc. But at the same time, artificial intelligence cannot compete with the human in the issues of a comprehensive analysis of a particular problem; in giving an assessment of the fairness and honesty of the person who has applied. The field of law cannot be translated into a programming language due to the variety of terms, categories and differences in their interpretation by sectors; law has no clear boundaries and framework. High-quality professional legal activity is possible only with the participation of a professional lawyer with experience in this field. It is difficult to imagine a robot that is performing functions of a representative in court or a robot-scientist (lawyer). Artificial intelligence today can perform almost any routine mechanical work with much greater productivity, and the activities of a lawyer are aimed primarily at solving more complex intellectual problems.

Keywords: legal activity, automation, LegalTech, artificial intelligence, robot lawyer, smart contract.

\footnotetext{
${ }^{1}$ Kazan Federal University . e-mail: desmodium@rambler.ru. Tel: 89172830976

${ }^{2}$ Kazan Federal University . e-mail: desmodium@ rambler.ru. Tel: 89172830976

${ }^{3}$ Kazan Federal University . e-mail: desmodium@ @ambler.ru. Tel: 89172830976
} 


\section{Introduction}

The rapid development of LegalTech and robotisation in legal sphere cause for alarm among lawyers. It is difficult to say how the legal profession will change in the future; however, the results of on-going processes on optimizing legal services in certain areas are already noticeable today. For example, various online services are gaining popularity on the Internet, allowing clients to get in real time such legal services as compiling and filing complaints with the relevant state authorities on housing and communal services, insurance services, contesting fines, registering legal entities or trademarks etc. Moreover, it must be recognized that, sometimes the proposals for the provision of such legal services on the Internet are quite intrusive.

At the same time, one should pay tribute to the fact that the rapid development of IT-technologies, artificial intelligence, of course, affects the labour market. In this regard, papers on replacing jurists (including judges and lawyers) with robots, introducing artificial intelligence, are increasingly found in periodical literature. But is it worth rushing about such sad conclusions? We try to figure this out.

\section{Methods}

The main methods that were used during the writing of this work are: comparative legal method, a complex analysis method, an interpretation method, a sociological method, a system analysis method, and an intersectoral approach.

\section{Results and discussion}

The advantage of modern computer technologies is that they are able to process a huge amount of information in a short time, without being subjected to subjective factors such as fatigue, poor health, etc., and also do not require payment of wages. There is no doubt that in the foreseeable future, artificial intelligence will be actively used in the legal profession. Already today, in many large organizations, standard forms of statements of claim and contracts are used, which greatly facilitates the process of preparing texts of planned agreements and lawsuits in court, without attaching any special mental costs. 
For many years now, discussions have been held about the possibility of replacing lawyers with artificial intelligence. Analysing the impact of automation on the legal profession, John Markoff examines the prospects of replacing the army of expensive lawyers with cheaper software [1] using the example of individual American companies. In the Russian periodicals, there are also loud statements about the commissioning of robots-lawyers which are trained to prepare lawsuits and which could replace many employees of legal departments of organizations [2].

We would like to pay special attention to the fact that the question of creation of a robot lawyer is also actively discussed within the walls of Kazan Federal University. So, on the initiative of KFU rector Ilshat Gafurov, the University launched the project “Artificial Intelligence in Law", which involves the Faculty of Law and the mathematical block of the University. According to the developers of the project, the introduction of third-party objective control based on the analysis of legislative data and court decisions adopted in the past can reduce the number of opportunities for corruption. Moreover, the authors of the project are convinced that the adoption of illogical decisions becomes noticeable and can be easier challenged in the courts of higher jurisdiction, which means that the number of judicial errors may decrease [3].

It is also necessary to mention the distribution of so-called "smart" contracts, the use of which is becoming fashionable in today's business environment. In general, a smart contract is a kind of program code (software) that can be executed automatically without the direct participation of the parties. According to A. Vashkevich, "business needs automation of legal relations in order to less depend on the will of parties, to prevent violations, to be aware about violations at the time of their commission. The potential of smart contracts operating in the real economy lies in many ways in their connection with the Internet of things, external information systems and registries. Smart contracts can be either an independent contractual instrument or an element of a more complex set of obligations, some of which are regulated by ordinary (paper) documents”. [4] 
We acknowledge that the question of the legal nature of smart contracts remains open. Without going into discussion, we note that such "smart" contracts are not contracts in the usual sense, but only some automated mechanisms for fulfilling the obligations of the contracting parties [5]. It seems that the use of smart contracts in practice will not lead to the complete disappearance of the legal profession. In general, the effectiveness of the organization based on robotic contractual work without the participation of professional lawyers should be called into question.

The introduction of artificial intelligence in professional legal activity is also being considered at the state level. So, in 2017, the Government of the Russian Federation approved a program for the development of the digital economy within the framework of which, among other things, an action plan was prepared to create a machinereadable language for norm-setting and the use of artificial intelligence to analyse the content of legal acts [6]. In the same year, the Project Activity Department in the Government of the Russian Federation put forward ideas for
400

improving legal activities. In particular, it is proposed to create electronic codes and an automated system for monitoring judicial practice, as well as the generation of standard court decisions using artificial intelligence [7]. In addition, the Ministry of Justice of the Russian Federation presented its draft Concept for regulating the market of professional legal activities, according to which the main problem of the legal services market in Russia is their low quality. According to the authors of the Concept, it is possible to eliminate this problem by introducing a lawyer monopoly on the provision of paid legal services, and the guarantor of the quality of such services will be corporate and management tools and advocacy selfregulation, including the Code of Professional Ethics of a lawyer and standards for the provision of qualified legal assistance [8].

In our opinion, despite such intensification of the development of artificial intelligence and attempts at its normative consolidation, there are a number of factors that indicate the impossibility of a complete robotisation of law. 
First, what is a robot-jurist? This is some kind of software equipped with data on a huge number of regulatory legal acts, various forms, contract templates, powers of attorney, statements, and court decisions, which are based on specific commands (algorithm of actions). During operation, such a program is able to quickly solve the task assigned to it. But at the same time, for the functioning of a robot-jurist, as well as for any software, it requires maintenance, updating, modification, debugging and other actions on the part of man. In other words, without the participation of a person having the necessary knowledge and experience, the effective functioning of artificial intelligence in the legal sphere is impossible.

In addition, the most important property of law is the ambiguity of terminology and the lack of unity in interpretation. "In order to translate norms containing ambiguous terms into a computer language, we will have to make too many reservations and exceptions, which will complicate the computerisation of law. Therefore, first we have to change the law so that its
401

terms would have the same content, and in all laws. That is titanic labour!". [9]

T.S. Nikiforova and K.M. Smirnov rightly note that "one of the constraining factors in the automation of legal activity is the conservatism of the Russian judicial system. Despite the fact that e-mail and digital signature were invented a long time ago, progress in communication with the courts did not move much. Valuable letters with notifications are still sent, many-hoursto-wait queues are still preserved. Therefore, a great potential for automating the work of jurists is seen in the establishment of a full-fledged electronic document management with the courts". [10]

It seems that at present robots could replace jurists only when performing routine tasks that can be programmed, such as drawing up simple template contracts, lawsuits, searching for judicial practice, analytical information, transferring documents to court, etc. But at the same time, artificial intelligence cannot compete with the human in issues of a comprehensive analysis of a particular problem, to assess the good faith, and honesty of the person who has applied. 
Analysing the work of online services in the legal services market, A. Bychkov comes to the conclusion that with the help of such services, one or several documents can be drawn up, it is possible to understand to which competent authorities it should be applied for obtaining the desired result. However, high-quality professional protection and representation of interests, if not with a specific, then at least with a predicted result, are possible only when contacting lawyers with experience in the relevant field to which the corresponding problem belongs. According to the author, these tools allow lawyers to facilitate the implementation of current tasks, minimize labour costs and focus their attention on more complex issues that require deep and detailed study [11].

Kevin D. Ashley holds a similar position, noting that when considering specific cases in court, a judge is responsible for making a legitimate, reasonable and fair decision, and modern automated technologies should be used to help judges make decisions in the case [12].

We must agree with the statement of A.A. Ivanov, who points out
402

that "it is impossible to fully automate either lawmaking or law enforcement. Artificial intelligence can be used in these areas, but it should play a secondary role, helping a person to detect contradictions in the rule of law, to see their duplication (redundancy) or inconsistency. But that's all! The decision about what these norms are and how to apply them, in the end, must be human-made". [4]

From our point of view, it is impossible to completely entrust artificial intelligence with the solution of legal issues, ultimately, this can lead to the disappearance of law in general. The field of law cannot be translated into a programming language, due to the variety of terms, categories and differences in their interpretation by industries; law has no clear boundaries and framework. High-quality professional legal activity is possible only with the participation of a professional lawyer with experience in this field. It is difficult to imagine a robot performing functions of a representative in court or a robot scientist (jurist). Artificial intelligence today can perform almost any routine mechanical work with much greater productivity, and the 
activities of a lawyer are aimed primarily at solving more complex intellectual problems.

\section{Summary}

We believe that one should not underestimate the importance of the legal profession and talk about its further disappearance, referring to the emergence of new automated mechanisms in the field of LegalTech. Such a danger is greatly exaggerated, since digitalization is primarily aimed at solving routine mechanical operations, and the field of professional activity of highly qualified lawyers does not have a strictly limited scope, and the functions performed by them are too diverse. On the contrary, well-planned, thought-out and implemented in a dosed sequence processes of legal activity digitalization in the short term can lead to the emergence of new related specialties and additional jobs.

\section{Conclusions}

The problems of law sphere robotisation that we have identified are extremely relevant and debatable. But it should be recognized that time does not stand still and dictates its conditions, requiring a change in the forms and methods of carrying out legal activities. Robotisation is possible for most routine legal processes through modern technology through implementation of LegalTech tools. With some accuracy, we can say that changes (albeit not in the near future) will occur, and the legal community should be ready for them. At the same time, one should not rely on the fact that artificial intelligence can completely replace the living mind and professional skills of a lawyer.

\section{Acknowledgments}

The work is performed according to the Russian Government Program of Competitive Growth of Kazan Federal University.

\section{References}

See: Markoff John. Armies of expensive lawyers replaced by cheaper software // The New York Times. - 2011. - 4 March. URL:

https://www.nytimes.com/2011/03/05/s cience/05legal.html

See: Robot-jurist will replace 3000 employees of Sberbank // Vedomosti. - 
Periódico do Núcleo de Estudos e Pesquisas sobre Gênero e Direito

Centro de Ciências Jurídicas - Universidade Federal da Paraíba V. 8 - No 06 - Ano 2019 - Special Edition ISSN | 2179-7137 | http://periodicos.ufpb.br/ojs2/index.php/ged/index
2017.

URL:

https://www.vedomosti.ru/finance/news

/2017/01/12/672785-robot-yurist-

ostavit-bez-raboti

See: Robot-jurist will be developed in KFU

//

URL:

https://kpfu.ru/news/rektor-254492.html

Kondrashov I., Ivanov A., Zschage H., Pronin A., Sergo A., Gastayer T., Vashkevich A., Kvitko R., Nesterenko A., Savelyev A., Pereverzev S., Kalyatin V., Budylin S. LegalTech and lawyers of the future // Law. - 2017. - No. 11. Pp. 20-36.

See more details in: Lim C., Saw T., Sargeant C. Smart Contracts: Bridging the Gap Between Expectation and Reality.URL:

https://law.ox.ac.uk/business-law-

blog/blog/2016/07/smart-contracts-

bridging-gap-between-expectation-and-

reality

See: Order of the Government of the Russian Federation dated July 28, 2017 No. 1632-r "On approval of the program "Digital Economy in the Russian Federation "// Collection of Legislation
404

of the Russian Federation. - 07.08.2017 -

No. 32. - Art.5138

See: Judicial Processor: Government discusses the use of artificial intelligence in the legal field // Kommersant. - 2017 .-- November $13 . \quad$ URL: https://www.kommersant.ru/doc/346618 $\underline{5}$

See: Draft Concept of Regulation of the Professional Legal Aid Market // URL: http://minjust.ru/en/deyatelnost-v-sfereadvokatury/proekt-koncepciiregulirovaniya-rynka-professionalnoyyuridicheskoy

Ivanov A.A. On the depth of the mechanization of law // Law. - 2018. No. 5. - Pp. 35-41.

Nikiforova T.S., Smirnova K.M. Will robots leave lawyers without job? // Law. - 2017. - No. 11. - Pp. 110-123.

See: Bychkov A. Robots, lawyers of the future. How the legal services market is changing // Financial newspaper. - 2016. - No. 33. - Pp. 11-12. 
See: Ashley K.D. Artificial Intelligence

and Legal Analytics: New Tools for Law

Practice in the Digital Age Paperback.

Cambridge: Cambridge University

Press, 2017 